Marcin BERLIK, Tomasz EWERTOWSKI, Małgorzata SŁAWIŃSKA

Poznan University of Technology (Politechnika Poznańska)

\title{
OVERVIEW OF THE WORKLOAD ASSESSMENT METHODS IN THE ASPECT OF IMPROVEMENT OF THE OPERATOR-TECHNICAL SUBSYSTEM RELATIONS ON THE EXAMPLE OF A PILOT
}

\section{Przegląd metod oceny obciążenia zadaniowego w aspekcie doskonalenia układów operator - obiekt techniczny na przykładzie pilota}

\begin{abstract}
The aim of the paper is to provide an overview of the pilot workload assessment methods taking into account their applicability, reliability and use in shaping flight safety. This article discusses some subjective and objective methods, and also discusses the role of observation and audit of the crew during the flight. The analysis performed was based on the concept of monitoring the safety and quality of performing the operations. Based on Heinrich's Law, which differentiates between three basic safety approaches: reactive, proactive and predictive, the possibilities of applying particular methods in the abovementioned safety approaches have been presented.
\end{abstract}

Keywords: flight safety, workload, anthropotechnical system, operator reliability

Streszczenie: Celem publikacji jest dokonanie przegladu metod oceny obciażenia zadaniowego pilota z uwzględnieniem możliwości ich zastosowania, wiarygodności oraz wykorzystania $w$ ksztaltowaniu bezpieczeństwa lotów. $W$ artykule omówiono niektóre metody subiektywne, obiektywne, a także rolę obserwacji i audytu zatogi w trakcie trwania lotu. Analize wykonano w oparciu o koncepcję monitoringu stanu bezpieczeństwa i jakości wykonywania operacji. Bazują na prawie Heinricha, charakteryzujacym trzy podstawowe podejścia do bezpieczeństwa: reaktywne, proaktywne oraz predyktywne, zaprezentowano możliwości zastosowania poszczególnych metod $w$ wyżej wymienionych podejściach do bezpieczeństwa.

Słowa kluczowe: bezpieczeństwo lotów, obciążenie zadaniowe, układ antropotechniczny, niezawodność operatora 


\section{Introduction}

Human activity has a big impact on the functioning of technical systems. The error of the operator of technical devices is often the cause of safety threat, as indicated by statistical data in the area of investigating the causes of accidents. Despite this, the human factor is monitored to an incomparably smaller extent than technical factors. In the situation in which most of the aircraft parameters are registered, human is usually monitored only by recording their voice. The basic criterion for assessing the level of safety is reliability. Reliability is the property of an object that determines whether it works correctly, accomplishes all the functions and actions entrusted to it for the required time and under certain operating conditions in a given set of forcing factors. Using the reliability indicators in the diagnosis of system relations, conditions for the synthesis of knowledge on various elements cooperating with each other, both technical and biological, appear. For humans this may be the cause of negative effects of overload, which is fatigue. Typical symptoms of fatigue are primarily: concentration and perceptiveness problems, slower thinking, memory impairment, depression, weakness and drowsiness $[1,9,12]$.

When measuring the dependent variable, the fallibility, there are following substantive approaches possible: 1) using the estimate scale in the observation and self-observation version, e.g. in determining one's own fallibility; 2) counting errors, slips, lapses, etc., either in direct observation or recording at the time of committing, and ex post; 3 ) collecting data on potential errors based on the statements of people using the device; 4) analyzing the time courses of activities, which are particularly important in the working structure of the entire system in which a person is one of the links; 5) measuring the psychological workload of the operator in specific situations, while performing the task; 6) measuring the subjective human states, and 7) analyzing the individual human characteristics. Using the aforementioned infallibility indicators in relation to man, one must bear in mind that this feature of a human is not constant but varies over time and is determined by changes in the environment and in a human himself.

\section{The concept of monitoring the safety and quality of performing the operations}

The aviation activity is based on the concept of monitoring the safety and quality of performing the operations. It consists of both subjective and objective 
methods. The observations and audit of the crew by the controlling persons are at the core of detection of nonconformities. It is done, for example, during schooling, test, examination or inspection flights. An important source of information are the crew's own reports. Currently, the capabilities of monitoring data from flight recorders and ground-based recording devices in the monitoring of the operator are used to a very low or zero degree. This creates a large area for exploration of this field with enormous potential.

Based on the Heinrich triangle, modified by Frank Bird and ConocoPhilips Marine, there are 30 serious accidents, 300 accidents, 3,000 incidents and 300,000 dangerous behaviors per one fatal accident. Three approaches to safety can be distinguished:

- reactive - actions are taken in response to the occurrence of events with large consequences. The principle is to analyze unwanted events that occurred in the past (catastrophe, breakdown, accident),

- proactive - actions are taken on the basis of events with small consequences in order to avoid events with large consequences (incidents, nonconformities),

- predictive - actions that try to predict future hazards, risks and events. The principle is to anticipate unwanted events in the system and warn about their occurrence (systems: TCAS, GPWS) [2].

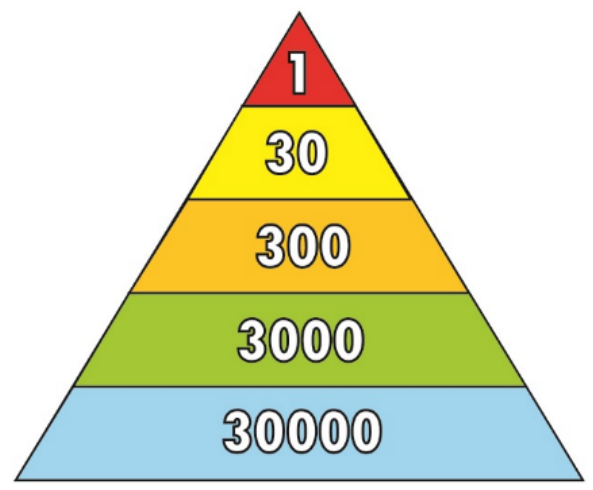

Fig. 1. H.W. Heinrich's triangle after a modification made by Bird and ConocoPhilips Marine, own elaboration based on [5] 


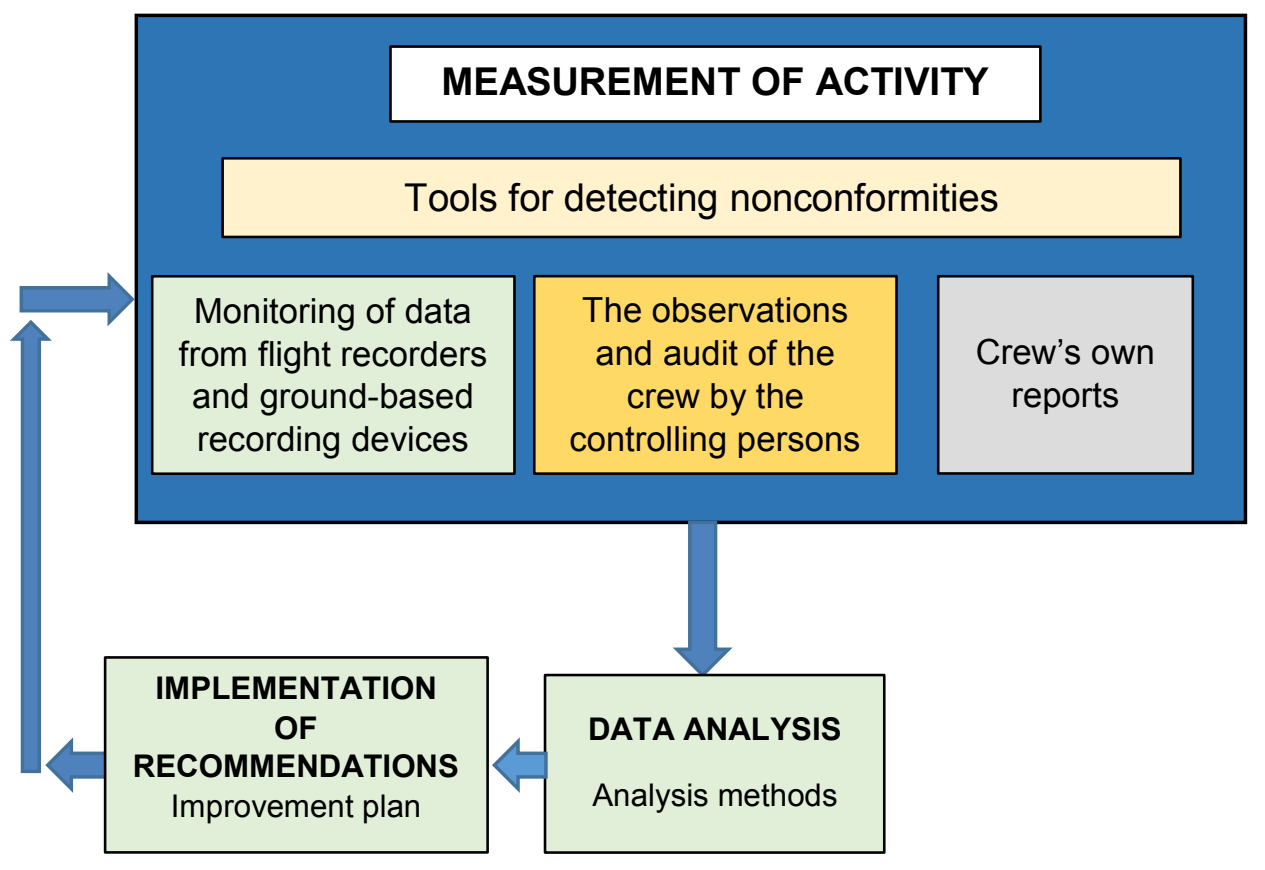

Fig. 2. The concept of monitoring the safety and quality of performing the operations, own elaboration based on [10]

\section{Crew's own reports}

The simplest methods, both when it comes to performing tests and interpreting their results, are subjective methods, based on questionnaires. They constitute a tool from the group defined in this article as "crew's own reports". An example of this method is the NASA-TLX (National Aeronautics and Space Administration Task Load Index) questionnaire, which was developed by Human Performance Group at the NASA Ames Research Center. It consists in filling in a questionnaire by the operator after completing the task. The subject assesses the level of their workload in six areas (mental workload, physical workload, time pressure, efficiency, effort and frustration). The assessment of each area is made on a twenty-point scale. The subject, however, does not provide numerical values, but marks the appropriate number of fields. Then, the individual areas are contrasted one by one in order that the subject can identify those in which they have experienced a greater workload. The advantage of this method is definitely the ease of testing. It does not require any tools other than the questionnaire itself. It takes several minutes to fill it in by the subject, also the interpretation of the results obtained is short and 
uncomplicated. In addition, the tests may be facilitated by applications available, among others, for the Android or mcOS system, or a sheet, which present readymade results [11]. Bedford Workload Scale is a similar tool. The subject evaluates their workload on a ten-point scale using supporting questions. The test lasts shorter than in the case of NASA TLX, and the results do not require processing. A common disadvantage of both methods is that the test can only be carried out after the task has been completed. McDonnell Rating Scale in which the subject assesses the workload on a ten-point scale, but prior to that, classifies them into categories and sub-categories defining: the ability to control the situation; workload as acceptable and unacceptable by the operator, and in the case of indicating the level of workload as acceptable, defining it as satisfactory or unsatisfactory $[4,8]$.

\section{Observations and audit of the crew by the controlling persons}

A very important source of information are observations and audits of crew in the air or on a flight simulator by a controlling person or instructor. Such observations are made during schooling, check, test, examination or inspection flights. In this case, the instructor observes and evaluates the decisions and actions taken by the crew during the flight. The number and type of errors made are the main determinants of the assessment. The errors determining the audit result are [7]:

- disqualifying errors - these are dangerous errors and errors distorting the course of the flight in a significant way, so that they raise great doubts as to the mastery of elements that constitute the essence of the task being performed;

- dangerous errors - errors that threaten the safety of the flight and errors that complicate the flight to the extent that in the case of more difficult conditions or less favorable circumstances can become dangerous errors;

- systematic errors - can transform into the habit of improper flying, even in the case when they are not dangerous or do not complicate performing of the task should be subjected to in-depth analysis.

\section{Monitoring of data from flight recorders and ground- based recording devices}

The methods related to the monitoring of data from flight recorders and ground-based recording devices are based on objective methods of measuring the 
response of the human body to workload changes. We count it according to the adopted scheme for the methods of data analysis from flight data recorders (for operational or catastrophic use) or from ground-based recording devices. This group includes a number of methods that record the changes of one or several physiological parameters. A significant advantage of these methods is the inability to distort the results by the subject. However, they are more difficult to carry out, are more time-consuming and require greater competence on the part of the person involved.

An important group of parameters reflecting the human workload are parameters related to the functioning of the cardiovascular and respiratory systems. Thanks to the use of cheap and easily available devices, it is possible to measure many parameters. An example of such a device can be Holter ECG monitoring. It allows you to record the heartbeat continuously for many hours. Its small size allows you to measure parameters during the flight, but installation of the device and interpretation of the results requires considerable knowledge and skills. A slightly simpler device is a pulse oximeter that records blood oxygenation and pulse, exporting the results directly to the smartphone's memory, where they are saved. The disadvantage is fixing it on a finger, which may cause difficulties in the operator's performance of the task.

An interesting alternative can be to use a sport tester in the form of a wrist watch, which measures the pulse using electrodes attached with a special strap to the chest, or directly from the diodes installed in the wrist watch strap. This solution shortens the preparation for testing, and also significantly increases the subject's comfort. Some devices are equipped, among others, with a microphone, a position recorder according to GPS and GLONASS systems, an accelerometer, which allows recording additional parameters useful in a subsequent flight analysis. The device is fully compatible with the smartphone, so you can monitor the parameters in real time, but also has a built-in memory that allows you to record parameters continuously for several hours [6].

Another method concerns the measurement of brain wave activity using an electroencephalograph. Interpretation of readings of the classic encephalograph, which measures using several dozen electrodes, is complicated and requires specialized knowledge. In addition, its installation is time-consuming and can make it difficult for the operator to perform tasks. As can be seen from the research carried out at the Poznan University of Technology, MindLink or MindWave devices can be successfully used for this purpose [3]. These are simplified electroencephalographs fixed e.g. in the form of a headband, which due to the use of a series of simplifications require the use of 2-3 diodes. The device measures brain wave activity, which allows the state of concentration and relaxation of the 
subject to be recorded. The results are saved using the application, and their interpretation is not time-consuming.

\section{Summary}

The above-mentioned methods can be divided according to the possibility of using them in specific approaches to safety management. The division is presented in the table below.

Table 1

The possibility of using selected methods in individual approaches to safety management

\begin{tabular}{|c|c|c|c|}
\hline Method/ Approach & Reactive & Proactive & Predictive \\
\hline NASA-TLX & & $\mathbf{x}$ & \\
\hline Bedford Workload Scale & & $\mathbf{x}$ & \\
\hline McDonnell Rating Scale & & $\mathbf{x}$ & $\mathbf{x}$ \\
\hline Sport tester & $\mathbf{x}$ & $\mathbf{x}$ & $\mathbf{x}$ \\
\hline EEG & $\mathbf{x}$ & $\mathbf{x}$ & $\mathbf{x}$ \\
\hline Observation of the crew & & & \\
\hline
\end{tabular}

Questionnaire methods were only assigned to a proactive approach. They are not useful in the case of an accident investigation due to the need for the subject to complete the questionnaire, which would often be impossible, and there would be also a high probability of providing insincere answers. In the case of attempts to use these methods in a predictive approach, it may be difficult to find the reasons for the excessive workload, the result refers to the whole flight. In order to identify the situation generating an excessive workload, it would be necessary to analyze the entire flight or indicate a problematic part of the flight by the subject.

Full versatility of use is characteristic to methods related to the recording of physiological parameters. The inability to manipulate test results by the subject is a huge advantage. In addition, the time of rapid changes in parameters or their persistence at an extremely low or high level can be found very quickly, thanks to 
which it is possible to analyze the remaining flight parameters in a given time period. In the case of recording the operator's parameters using a flight recorder, it is also possible to use the data in case of death of the crew (reactive approach). The test results can be used to investigate incidents (proactive approach) and indicate situations of excessive or too low operator workload, which did not result in deviation of flight parameters, or crew errors, but may be useful in forecasting unwanted events and preventing them in the future (predictive approach).

The observation of the crew allows noticing errors and deviations during the flight, which, after analysis and discussion, can be used to increase safety in the future (proactive approach). In addition, in the case of noticing significant errors that threaten the safety of the flight, the instructor has the right to interfere in the course of the flight both verbally and by responding with yokes. Some of the forms of interference used include giving a warning, hint, correcting an error, and, if necessary, taking over the yoke (predictive approach).

\section{Conclusions}

- Currently, monitoring of the operator (pilot) reliability is based mainly on subjective methods. One should strive for the maximum objectivity of the monitoring in question.

- In modern safety management systems, a proactive and, where possible, predictive approach should prevail.

- From analyzed methods of operator workload assessment, the most universal and objective methods are those using the recording of human physiological parameters on on-board recording devices.

- The subjective methods are burdened with a one-sided and biased assessment of the performed task by the operator and should constitute only a supplementary element of the overall monitoring and assessment of the safety of the operation being performed.

- There is a possibility of partial objectivization of subjective methods. Recording the physiological parameters of the crews can significantly contribute to the increase in the safety of flight operations.

- Differences, occurring after the analysis of the safety of the task performed by the operator, between the results obtained using objective and subjective methods are an indicator of the culture, safety and culture, and are the basis for assessing the attitude of the operator. 


\section{References}

1. Berlik M., Dahlke G., Sławińska M.: The Idea of Modification of Work Conditions for the Reduction of the Pilot's Workload in a Glider, Type SZD-30. Journal of KONBiN, Vol. 45, 2018, DOI 10.2478/jok-2018-0001.

2. Ewertowski T., Berlik M., Sławińska M.: Koncepcja oceny obciążenia zadaniowego w aspekcie doskonalenia układów operator - obiekt techniczny na przykładzie pilota. Zeszyty Naukowe Politechniki Poznańskiej. Organizacja i Zarządzanie, No. 79, 2019.

3. Galant M., Merkisz J.: Badania zmian koncentracji kierowcy w czasie treningu symulatorowego. Logistyka, No. 3, 2015.

4. Gawron V.J.: Human Performance, Workload, and Situational Awareness Measures Handbook, 2018.

5. Heinrich H., Industrial Accidents Prevention, New York, Toronto, London, Mc Graw Hill Book Company, Inc. 1959.

6. Makarowski R.: Ryzyko i stres w lotnictwie sportowym. Difin, 2010.

7. Pazio A, Winczo J.: Metodyka szkolenia szybowcowego. Wydawnictwa Komunikacji i Łączności, 1975.

8. Scobba T. et al. Space Safety and Human Performance, Cambridge 2018.

9. Sławińska M., Więcej-Janka E., Berlik M., Galant M.: Metody oceny wpływu kontekstu sytuacyjnego zadań operatorskich na ocenę ergonomiczności urządzeń sterowniczych, Zeszyty Naukowe Politechniki Poznańskiej. Organizacja i Zarządzanie, No. 77, 2018.

10. Speyer J.J.: The Flight Operations Monitoring System, HCI-02 Proceedings, Blagnac. 2002.

11. Task load index (NASA-TLX), https://humansystems.arc.nasa.gov/groups/TLX/downloads/TLX.pdf, 30.11.2018.

12. Zając M., Świeboda J.: The method of error elimination in the process of container handling. In Military Technologies (ICMT), IEEE, International Conference 2015. 


\section{PRZEGLĄD METOD OCENY OBCIĄŻENIA ZADANIOWEGO W ASPEKCIE DOSKONALENIA UKLADÓW OPERATOR - OBIEKT TECHNICZNY NA PRZYKLADZIE PILOTA}

\section{Wprowadzenie}

Działanie człowieka ma duży wpływ na funkcjonowanie systemów technicznych. Błąd operatora urządzeń technicznych jest często przyczyną zagrożenia bezpieczeństwa, na co wskazują dane statystyczne w obszarze badania przyczyn wypadków. Pomimo to czynnik ludzki jest monitorowany w nieporównywalnie mniejszym stopniu niż czynniki techniczne. W sytuacji, w której rejestrowana jest większość parametrów statku powietrznego, człowiek najczęściej monitorowany jest jedynie poprzez zapis jego głosu. Podstawowym kryterium oceny poziomu bezpieczeństwa jest niezawodność. Niezawodność jest to właściwość obiektu mówiąca o tym, czy pracuje on poprawnie, spełnia wszystkie powierzone mu funkcje i czynności przez wymagany czas i w określonych warunkach eksploatacji w danym zespole czynników wymuszających. Wykorzystując wskaźniki niezawodności w diagnozowaniu relacji systemowych powstają warunki do syntezy wiedzy dotyczącej różnych elementów współpracujących ze sobą, zarówno technicznych, jak i biologicznych. Dla człowieka mogą to być przyczyny ujemnych skutków przeciążenia, którym jest zmęczenie. Typowymi objawami zmęczenia są przede wszystkim: osłabienie uwagi, osłabienie spostrzegawczości, spowolnienie myślenia, zaburzenia pamięci, przygnębienie, osłabienie oraz senność $[1,9,12]$.

Przy pomiarze zmiennej zależnej - zawodności możliwe są następujące podejścia merytoryczne: 1) stosowanie skal szacunkowych w wersji obserwacyjnej i samoobserwacyjnej, np. przy określaniu poczucia własnej niezawodności; 2) zliczanie błędów, potknięć, uchybień itp. zarówno w bezpośredniej obserwacji czy rejestracji w momencie ich popełnienia, jak i ex post; 3) zbieranie danych o potencjalnych błędach na podstawie wypowiedzi osób użytkujących dane urządzenie; 4) analiza czasowych przebiegów czynności, szczególnie ważnych w strukturze działania całego układu, w którym człowiek jest jednym z ogniw; 
5) pomiar obciążenia psychicznego operatora w określonych sytuacjach wykonywanego zadania; 6) pomiar subiektywnych stanów człowieka oraz 7) analiza indywidualnych cech człowieka. Stosując wyżej wymienione wskaźniki niezawodności w odniesieniu do człowieka należy pamiętać, że ta jego cecha nie jest wielkością stałą, lecz zmienia się w miarę upływu czasu i jest uwarunkowana zmianami zachodzącymi w otoczeniu oraz w samym człowieku.

W niniejszym artykule scharakteryzowano wybrane metody badawcze, których zastosowanie może przyczynić się do poprawy warunków niezawodnego funkcjonowania człowieka w układzie z elementami technicznymi złożonych systemów techniczno-społecznych.

\section{Koncepcja monitoringu stanu bezpieczeństwa i jakości wykonywania operacji}

W działalności lotniczej bazuje się na koncepcji monitoringu stanu bezpieczeństwa i jakości wykonywania operacji. Składają się na nią zarówno metody subiektywne, jak i obiektywne. Trzon detekcji niezgodności stanowią obserwacje i audyt załogi przez osoby kontrolujące. Ma to miejsce np. podczas lotów szkolnych, kontrolnych, egzaminacyjnych czy inspekcyjnych. Ważne źródło informacji stanowią raporty własne załogi. Aktualnie w bardzo niewielkim bądź zerowym stopniu wykorzystuje się możliwości monitorowania danych z rejestratorów lotu i naziemnych urządzeń rejestrujących w zakresie monitorowania operatora. Stwarza to duże pole do eksploracji tego obszaru.

W oparciu o zmodyfikowany przez Franka Birda oraz firmę ConocoPhilips Marine trójkąt Heinricha, na jedenp wypadek śmiertelny przypada 30 poważnych wypadków, 300 wypadków, 3000 incydentów oraz 300000 niebezpiecznych zachowań. Wyodrębnić można trzy podejścia do bezpieczeństwa:

- reaktywne - działania podejmowane są w odpowiedzi na wystąpienie zdarzeń o dużych skutkach. Zasadą jest analiza zdarzeń niepożądanych, które zaistniały w przeszłości (katastrofa, awaria, wypadek);

- proaktywne - działania podejmowane są na podstawie zdarzeń o małych skutkach w celu uniknięcia zdarzeń o dużych skutkach (incydenty, niezgodności);

- predyktywne - działania, które próbują przewidywać przyszłe zagrożenia, ryzyka i zdarzenia, zasadą jest przewidywanie zdarzeń niepożądanych w systemie i uprzedzanie ich wystąpienia (systemy: TCAS, GPWS) [4]. 


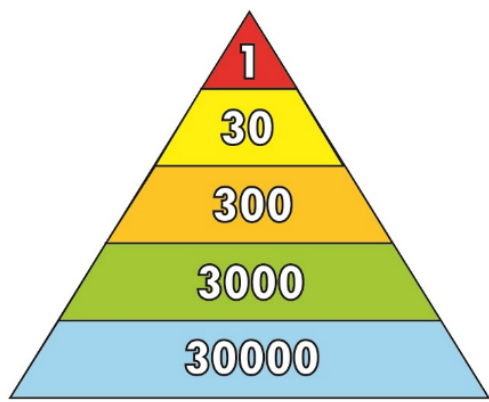

Rys. 1. Trójkąt H.W. Heinricha po modyfikacji wykonanej przez Birda oraz firmę ConocoPhilips Marine [5]

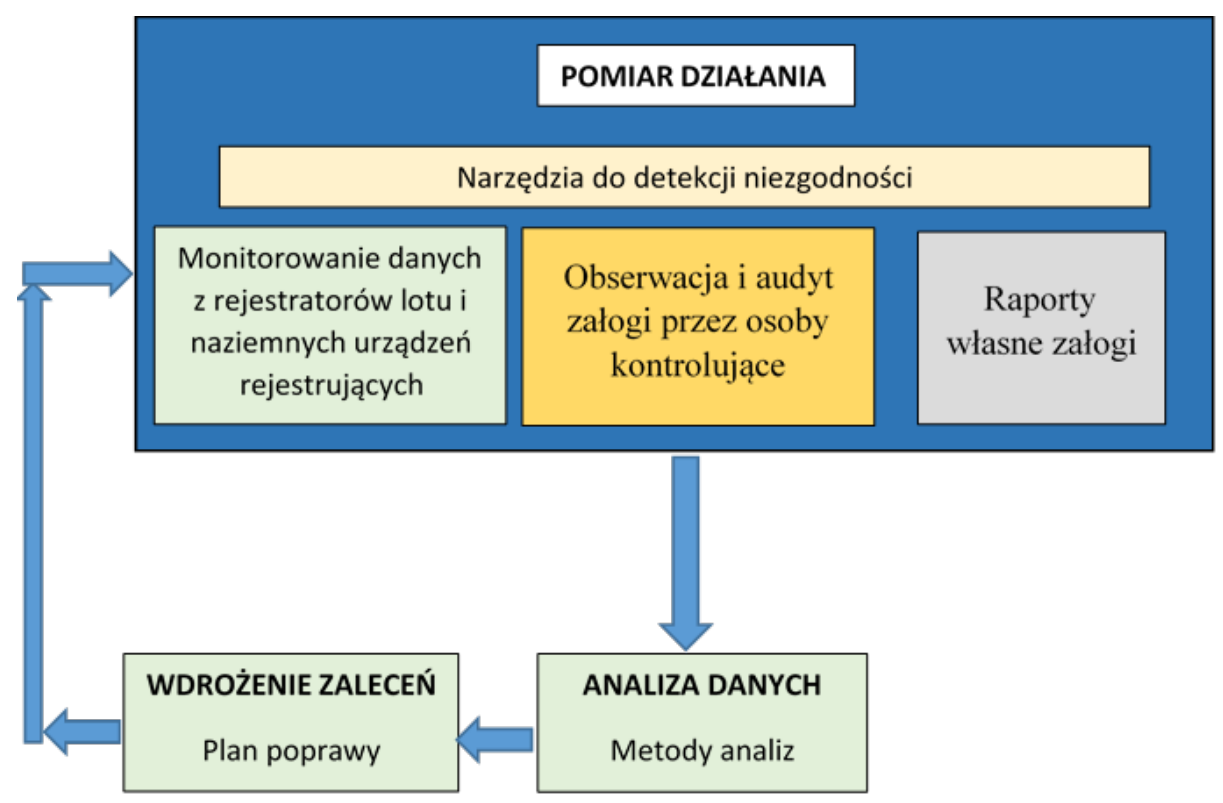

Rys. 2. Koncepcja monitoringu stanu bezpieczeństwa i jakości wykonywania operacji [10]

\section{Raporty własne załogi}

Najprostszymi metodami, zarówno jeśli chodzi o wykonanie badań, jak i interpretację ich wyników, są metody subiektywne, bazujące na kwestionariuszach. Stanowią one narzędzie $\mathrm{z}$ grupy określonej $\mathrm{w}$ niniejszym artykule jako raporty własne załogi. Przykładem tej metody jest kwestionariusz NASA-TLX (National Aeronautics and Space Administration Task Load Index), opracowany przez Human Performance Grup w Ames Research Center NASA. Operator wypełnia 
kwestionariusz po wykonaniu zadania. Ocenia poziom swojego obciążenia zadaniowego w sześciu obszarach (obciążenie umysłowe, obciążenie fizyczne, presję czasu, wydolność, wysiłek i frustracja). Każdy obszar oceniany jest w 20stopniowej skali. Badany jednak nie podaje wartości liczbowych, a zakreśla odpowiednią liczbę pól. Następnie przeciwstawiane są sobie kolejno poszczególne obszary tak, aby badany wyłonił spośród nich te, w których odczuwał większe obciążenie.

Zdecydowaną zaletą takiej metody jest łatwość przeprowadzenia badania. Nie wymaga ono żadnych narzędzi poza samym kwestionariuszem. Wypełnienie go przez badanego trwa kilka minut, także interpretacja uzyskanych wyników jest krótka i nieskomplikowana. Dodatkowo przeprowadzenie mogą ułatwić aplikacje dostępne m.in na system Android, czy mcOS, czy arkusze, które prezentują gotowe wyniki badań [11].

Podobne narzędzie stanowi Bedford Workload Scale. Badany ocenia swoje obciążenie w 10-stopniowej skali przy pomocy pytań pomocniczych. Badanie trwa krócej niż w przypadku NASA TLX, a wyniki nie wymagają obróbki. Wspólną wadą obu omówionych metod jest to, iż badanie można przeprowadzić dopiero po zakończeniu zadania. McDonnell Rating Scale, w której badany ocenia obciążenie w 10-stopniowej skali, uprzednio szeregując je do kategorii i podkategorii określających: możliwość kontrolowania sytuacji; obciążenie jako akceptowalne i nieakceptowalne przez operatora, a w przypadku wskazania poziomu obciążenia jako akceptowalnego określenie go jako satysfakcjonującego lub niesatysfakcjonującego $[4,8]$.

\section{Obserwacje i audyt załogi przez osoby kontrolujące}

Bardzo istotnym źródłem informacji są obserwacje i audyty załogi w powietrzu lub na symulatorze lotu przez osobę kontrolującą lub instruktora. Obserwacji takich dokonuje się podczas lotów szkolnych, sprawdzających, kontrolnych, egzaminacyjnych czy inspekcyjnych. W takim przypadku instruktor obserwuje i ocenia decyzje i czynności podejmowane przez załogę podczas trwania lotu. O ocenie decyduje przede wszystkim liczba oraz rodzaj popełnionych błędów. Błędy decydujące o wyniku audytu to [7]:

- błędy dyskwalifikujące - są to błędy niebezpieczne oraz błędy zniekształcające w znaczący sposób przebieg lotu, tak iż budzą dużą wątpliwości co do opanowania elementów, które stanowią istotę realizowanego zadania;

- błędy niebezpieczne - błędy, które zagrażają bezpieczeństwu lotu, oraz błędy, które na tyle komplikują przebieg lotu, że w przypadku wystąpienia 
trudniejszych warunków lub mniej sprzyjających okoliczności mogą stać się błędami niebezpiecznymi;

- błędy systematyczne - mogą przekształcić się w nawyk nieprawidłowego pilotażu, nawet w przypadku gdy nie są niebezpieczne ani nie komplikują wykonania zadania, powinny być poddane dogłębnej analizie.

\section{Monitorowanie danych $\mathrm{z}$ rejestratorów lotu i naziemnych urządzeń rejestrujących}

Metody związane z monitorowaniem danych z rejestratorów lotu i naziemnych urządzeń rejestrujących bazują na obiektywnych metodach pomiaru reakcji organizmu człowieka na zmiany obciążenia. Zaliczamy je według przyjętego schematu do metod analizy danych z eksploatacyjnych lub katastroficznych rejestratorów parametrów lotu lub z naziemnych urządzeń rejestrujących. Do tej grupy zaliczamy szereg metod, które rejestrują zmiany jednego bądź kilku parametrów fizjologicznych. Dużą zaletę tych metod stanowi brak możności zniekształcenia wyników przez badanego. Są one natomiast trudniejsze do przeprowadzenia, bardziej czasochłonne oraz wymagają większych kompetencji ze strony badacza.

Ważna grupę parametrów odzwierciedlających obciążenie człowieka są parametry związane z funkcjonowaniem układu sercowo-naczyniowego oraz oddechowego. Dzięki wykorzystaniu tanich i łatwo dostępnych urządzeń istnieje możliwość pomiaru wielu parametrów. Przykładem może być monitorowanie EKG metodą Holtera. Umożliwia ona rejestrowanie pracy serca w sposób ciągły przez wiele godzin. Niewielki rozmiar urządzenia umożliwia pomiar parametrów w trakcie lotu, jednak jego instalacja oraz interpretacja wyników wymaga znacznej wiedzy i umiejętności. Nieco prostszym urządzeniem jest pulsoksymetr, który rejestruje utlenowanie krwi oraz puls, eksportując wyniki bezpośrednio do pamięci smartfona, gdzie są zapisywane. Wadę stanowi zamocowanie go na palcu, co może powodować trudności w wykonywaniu czynności przez operatora.

Ciekawą alternatywą może być wykorzystanie sport testera $\mathrm{w}$ formie naręcznego zegarka, który mierzy puls za pomocą elektrod przymocowanych specjalnym paskiem na klatce piersiowej lub bezpośrednio z diod zainstalowanych w pasku zegarka naręcznego. Takie rozwiązanie skraca przygotowanie do badań, a także zdecydowanie zwiększa komfort badanego. Niektóre urządzenia wyposażone są m.in. w mikrofon, rejestrator pozycji wg systemów GPS i GLONASS, przyspieszeniomierz, co umożliwia rejestrowanie dodatkowych parametrów przydatnych w późniejszej analizie lotu. Urządzenie jest w pełni kompatybilne ze smartfonem, dzięki czemu można monitorować parametry 
w czasie rzeczywistym, ale także posiada wbudowaną pamięć, umożliwiającą zapis parametrów nieprzerwanie przez kilka godzin [6].

Kolejna metoda dotyczy pomiaru aktywności fal mózgowych za pomocą elektroencefalografu. Interpretacja wskazań klasycznego encefalografu, który dokonuje pomiaru za pomocą kilkudziesięciu elektrod jest skomplikowana i wymaga specjalistycznej wiedzy. Ponadto jego montaż jest czasochłonny i może utrudniać wykonywanie zadań przez operatora. Jak wynika z badań przeprowadzonych na Politechnice Poznańskiej z powodzeniem mogą być stosowane do tego celu urządzenia typu MindLink, czy MindWave [3]. Są to uproszczone elektroencefalografy mocowane np. w formie opaski na głowę, które dzięki zastosowaniu szeregu uproszczeń wymagają użycia 2-3 diod. Urządzenie dokonuje pomiaru aktywności fal mózgowych, co pozwala na rejestrowanie stanu koncentracji oraz relaksacji badanego. Wyniki są zapisywane w aplikacji, a ich interpretacja nie jest czasochłonna.

\section{Podsumowanie}

Wymienione wyżej metody możemy podzielić ze względu na możliwość wykorzystania ich $\mathrm{w}$ poszczególnych podejściach do zarządzania bezpieczeństwem. Wspomniany podział przedstawia poniższa tabela.

Tabela 1

Możliwość wykorzystania wybranych metod w poszczególnych podejściach do zarządzania bezpieczeństwem

\begin{tabular}{|c|c|c|c|}
\hline Metoda/ Podejście & Reaktywne & Proaktywne & Predyktywne \\
\hline NASA-TLX & & $\mathbf{x}$ & \\
\hline Bedford Workload Scale & & $\mathbf{x}$ & \\
\hline McDonnell Rating Scale & & $\mathbf{x}$ & \\
\hline Sport tester & $\mathbf{x}$ & $\mathbf{x}$ & $\mathbf{x}$ \\
\hline EEG & $\mathbf{x}$ & $\mathbf{x}$ & $\mathbf{x}$ \\
\hline Obserwacja załogi & & $\mathbf{x}$ & $\mathbf{x}$ \\
\hline
\end{tabular}


Metody kwestionariuszowe przyporządkowano wyłącznie do podejścia proaktywnego. Nie są one użyteczne w przypadku badania wypadku ze względu na konieczność wypełnienia ankiety przez badanego, co często byłoby niemożliwe, a także istniałoby duże prawdopodobieństwo udzielenia nieszczerych odpowiedzi. W przypadku prób wykorzystania tych metod w podejściu predyktywnym trudność stanowić może odnalezienie przyczyn nadmiernego obciążenia, wynik odnosi się do całego lotu. W celu zidentyfikowania sytuacji generującej nadmierne obciążenie konieczne byłoby przeanalizowanie całego lotu lub wskazanie problematycznego fragmentu lotu przez badanego.

Pełna wszechstronność wykorzystania cechuje metody związane z rejestrowaniem parametrów fizjologicznych. Niemożność manipulowania wynikami badań przez badanego stanowi olbrzymią zaletę. Ponadto bardzo szybko można odnaleźć czas gwałtownych zmian parametrów lub utrzymywania się ich na wyjątkowo niskim lub wysokim poziomie, dzięki czemu możliwa jest analiza pozostałych parametrów lotu $\mathrm{w}$ danym odcinku czasu. W przypadku zapisu parametrów operatora przy użyciu rejestratora katastroficznego możliwe jest wykorzystanie danych także w przypadku śmierci załogi (podejście reaktywne). Wyniki badań mogą być użyte do badania incydentów (podejście proaktywne) oraz wskazywać na sytuacje nadmiernego bądź zbyt niskiego obciążenia operatora, które nie skutkowały odchyleniem zadanych parametrów lotu czy błędami załogi, ale mogą być przydatne $\mathrm{w}$ prognozowaniu niepożądanych zdarzeń oraz zapobieganiu im w przyszłości (podejście predyktywne).

Obserwacja załogi pozwala na zaobserwowanie błędów i odchyleń w trakcie lotu, które po przeanalizowaniu i omówieniu mogą służyć zwiększeniu bezpieczeństwa w przyszłości (podejście proaktywne). Ponadto w razie zaobserwowania znaczących błędów zagrażających bezpieczeństwu lotu instruktor ma możliwość podjęcia ingerencji $\mathrm{w}$ przebieg lotu zarówno werbalnie, jak i reagując sterownicami. Niektóre ze stosowanych form ingerencji to udzielenie ostrzeżenia, wskazówki, skorygowanie błędu, a w ostateczności przejęcie sterów (podejście predyktywne).

\section{Wnioski}

- Obecnie monitoring niezawodności operatora (pilota) opiera się głównie na metodach subiektywnych. Należy dążyć do maksymalnej obiektywizacji przedmiotowego monitoringu.

- W nowoczesnych systemach zarządzania bezpieczeństwem powinno dominować podejście proaktywne i w miarę możliwości predyktywne. 
- Z przeanalizowanych metod oceny obciążenia zadaniowego operatora najbardziej uniwersalne i zarazem obiektywne są metody wykorzystujące zapis parametrów fizjologicznych człowieka na pokładowych urządzeniach rejestrujących.

- Metody subiektywne obarczone są jednostronną oraz tendencyjną oceną operatora wykonywanego zadania i powinny stanowić jedynie element uzupełniający całościowego monitoringu i oceny bezpieczeństwa wykonywanej operacji.

- Istnieje możliwość częściowej obiektywizacji metod subiektywnych.

- Rejestrowanie parametrów fizjologicznych załóg może znacznie przyczynić się do wzrostu bezpieczeństwa wykonywania operacji lotniczych.

- Różnice występujące po przeprowadzeniu analizy bezpieczeństwa wykonywania zadania przez operatora pomiędzy wynikami pozyskiwanymi metodami obiektywnymi a subiektywnymi są wskaźnikiem kultury bezpieczeństwa organizacji i dają podstawę do oceny postawy operatora.

\section{Literatura}

1. Berlik M., Dahlke G., Sławińska M.: The Idea of Modification of Work Conditions for the Reduction of the Pilot's Workload in a Glider, Type SZD-30. Journal of KONBiN, Vol. 45, 2018, DOI 10.2478/jok-2018-0001.

2. Ewertowski T., Berlik M., Sławińska M.: Koncepcja oceny obciążenia zadaniowego w aspekcie doskonalenia układów operator - obiekt techniczny na przykładzie pilota. Zeszyty Naukowe Politechniki Poznańskiej. Organizacja i Zarządzanie, No. 79, 2019.

3. Galant M., Merkisz J.: Badania zmian koncentracji kierowcy $\mathrm{w}$ czasie treningu symulatorowego. Logistyka, No. 3, 2015.

4. Gawron V.J.: Human Performance, Workload, and Situational Awareness Measures Handbook, 2018.

5. Heinrich H., Industrial Accidents Prevention, New York, Toronto, London, Mc Graw Hill Book Company, Inc. 1959.

6. Makarowski R.: Ryzyko i stres w lotnictwie sportowym. Difin, 2010.

7. Pazio A, Winczo J.: Metodyka szkolenia szybowcowego. Wydawnictwa Komunikacji i Łączności, 1975.

8. Scobba T. et al. Space Safety and Human Performance, Cambridge 2018.

9. Sławińska M., Więcej-Janka E., Berlik M., Galant M.: Metody oceny wpływu kontekstu sytuacyjnego zadań operatorskich na ocenę ergonomiczności urządzeń sterowniczych, Zeszyty Naukowe Politechniki Poznańskiej. Organizacja i Zarządzanie, No. 77, 2018.

10. Speyer J.J.: The Flight Operations Monitoring System, HCI-02 Proceedings, Blagnac. 2002. 
11. Task load index (NASA-TLX), https://humansystems.arc.nasa.gov/groups/TLX/downloads/TLX.pdf, 30.11.2018.

12. Zając M., Świeboda J.: The method of error elimination in the process of container handling. In Military Technologies (ICMT), IEEE, International Conference 2015. 